\title{
Detection of circulating miRNAs: comparative analysis of extracellular vesicle-incorporated miRNAs and cell-free miRNAs in whole plasma of prostate cancer patients
}

Edgars Endzelinšš ${ }^{1 \dagger}$, Andreas Berger ${ }^{1 \dagger}$, Vita Melne ${ }^{1,2}$, Cristina Bajo-Santos ${ }^{1}$, Kristīne Soboḷevska ${ }^{1}$, Artūrs Ābols ${ }^{1}$, Marta Rodriguez ${ }^{3}$, Daiga Šantare ${ }^{4}$, Anastasija Rudn,ickiha ${ }^{1}$, Vilnis Lietuvietis ${ }^{1,2}$, Alicia Llorente $^{3}$ and Aija Line ${ }^{1 *}$ (D)

\begin{abstract}
Background: Circulating cell-free miRNAs have emerged as promising minimally-invasive biomarkers for early detection, prognosis and monitoring of cancer. They can exist in the bloodstream incorporated into extracellular vesicles (EVs) and ribonucleoprotein complexes. However, it is still debated if EVs contain biologically meaningful amounts of miRNAs and may provide a better source of miRNA biomarkers than whole plasma. The aim of this study was to systematically compare the diagnostic potential of prostate cancer-associated miRNAs in whole plasma and in plasma EVs.

Methods: RNA was isolated from whole plasma and plasma EV samples from a well characterised cohort of 50 patient with prostate cancer (PC) and 22 patients with benign prostatic hyperplasia (BPH). Nine miRNAs known to have a diagnostic potential for PC in cell-free blood were quantified by RT-qPCR and the relative quantities were compared between patients with PC and BPH and between PC patients with Gleason score $\geq 8$ and $\leq 6$.

Results: Only a small fraction of the total cell-free miRNA was recovered from the plasma EVs, however the EVincorporated and whole plasma cell-free miRNA profiles were clearly different. Four of the miRNAs analysed showed a diagnostic potential in our patient cohort. MiR-375 could differentiate between PC and BPH patients when analysed in the whole plasma, while miR-200c-3p and miR-21-5p performed better when analysed in plasma EVs. EV-incorporated but not whole plasma Let-7a-5p level could distinguish PC patients with Gleason score $\geq 8$ vs $\leq 6$.
\end{abstract}

Conclusions: This study demonstrates that for some miRNA biomarkers EVs provide a more consistent source of RNA than whole plasma, while other miRNAs show better diagnostic performance when tested in the whole plasma.

Keywords: Prostate cancer, Cell-free miRNAs, Extracellular vesicles, Exosomes, Microvesicles, Biomarkers, Liquid biopsy

\footnotetext{
* Correspondence: aija@biomed.lu.lv

${ }^{\dagger}$ Equal contributors

'Latvian Biomedical Research and Study Centre, Ratsupites Str 1, k-1, Riga

LV-1067, Latvia

Full list of author information is available at the end of the article
} 


\section{Background}

Circulating cell-free micro-RNAs (miRNAs) have emerged as promising biomarkers for the development of bloodbased assays for early detection, prognosis and monitoring of cancer. In 2008, Mitchell et al. demonstrated for the first time that miRNAs are released from prostate cancer (PC) cells into the bloodstream, where they exist in a remarkably stable form [1]. miRNAs were shown to remain stable after incubation of plasma or serum at room temperature for up to $24 \mathrm{~h}$ and to resist RNase A digestion, $\mathrm{HCl}$ and $\mathrm{NaOH}$ treatment or multiple freeze-thaw cycles $[1,2]$. Subsequently, the levels of circulating miRNAs have been studied in patients with various cancers, including PC, resulting in the discovery of individual miRNAs or miRNA signatures with diagnostic and/or prognostic value [3].

$\mathrm{PC}$ is the most frequently diagnosed cancer in males in Europe and the United States $[4,5]$. Currently, the serum PSA test is the most commonly used tool for organised screening programs, opportunistic screening and monitoring of PC [6]. However, PSA is not cancer specific and the high false-positive rate and low specificity leads to large numbers of unnecessary prostate biopsies and emotional morbidity [7]. Furthermore, PC is characterised by a highly heterogeneous course - one part of the patients develops a high-grade disease with extracapsular spread and distant metastases requiring aggressive treatment, while others have a relatively indolent, slowly progressing disease that could have been managed by active surveillance [8]. The current standard of care analyses, however, do not predict whether a histologically proven tumour will give rise to a clinically significant disease, leading to overtreatment of indolent PC. Hence, the greatest unmet clinical needs in the management of $\mathrm{PC}$ are sensitive and reliable noninvasive tools for differentiating between $\mathrm{PC}$ and benign prostatic diseases, and between potentially fast progressing PC requiring aggressive treatment and a relatively indolent disease that can be managed by active surveillance.

More than 20 studies investigating levels of cell-free miRNAs in plasma or serum of PC patients have been published up to date $[9,10]$. The majority of these studies were focused on the identification of circulating miRNAs that differentiate between patients with $\mathrm{PC}$ and benign prostatic hyperplasia (BPH) or healthy controls. Some of these studies have shown remarkably high diagnostic value. For example, Chen et al. identified a 5 miRNA panel that could differentiate PC from BPH with an AUC of 0.924 and PC from healthy controls with an AUC of 0.860 [11]. Some other studies have reported cell-free miRNAs that differentiate between localised and metastatic castration resistant prostate cancer (mCRPC) or between lowgrade and high-grade PC. For example, Mihelich et al. developed a "miRScore" that based on the serum levels of 14 miRNAs could predict absence of high-grade PC among men with $\mathrm{PC}$ and $\mathrm{BPH}$ with a negative predictive value of 0.939 [12]. However, relatively few miRNA biomarkers have been validated by several independent studies, while many other miRNAs either have been reported in a single study or show conflicting results $[3$, 10]. Therefore, the analysis of cell-free miRNAs is regarded as a poorly reproducible technique $[3,13,14]$.

Cell-free miRNAs circulating in the bloodstream have been found to be enclosed into extracellular vesicles (EVs) $[15,16]$, or to exist in a vesicle-free form associated with high-density lipoproteins [17], Ago2 protein [18, 19] or other RNA binding proteins [20]. The majority of the studies has used whole plasma or serum as a source of cell-free miRNAs. However, it has recently been hypothesised that cancer-derived EVs may be enriched with miRNA signatures reminiscent of their cell of origin, contain rare yet highly specific RNA biomarkers and protect their RNA cargo from degradation in the bloodstream and, therefore, the analysis of EV-enclosed miRNAs may be superior to whole plasma/serum analysis [10, 21, 22]. Nevertheless, to the best of our knowledge, a direct comparison of miRNA detection assays in whole plasma and plasma EVs has not been reported so far.

In this study, we evaluated the performance of 9 miRNA biomarkers previously reported to have a diagnostic or prognostic significance in $\mathrm{PC}$ by quantifying them in the whole plasma and plasma EVs in a cohort of $50 \mathrm{PC}$ and $22 \mathrm{BPH}$ patients.

\section{Methods}

\section{Study population and sample collection}

Patients with PC and BPH were recruited between September 2011 and December 2013 at Riga East University Hospital and subsequently were followed up until December 2016. The diagnosis was established using standard of care diagnostic examinations and Gleason score was determined according to standard histopathological criteria by an experienced pathologist.

Pre-treatment blood samples were collected into EDTAcoated tubes and processed at room temperature within $2 \mathrm{~h}$ of blood draw. Plasma samples were centrifuged twice for $10 \mathrm{~min}$ at $2000 \mathrm{~g}$, aliquoted and stored at $-80{ }^{\circ} \mathrm{C}$ until analysis. The samples were deposited into the Latvian Genome Database. Biobanking procedures were approved by the Committee of Medical Ethics of Latvia and the use of clinical samples for the research was approved by the Committee of Biomedical Ethics of Riga East University Hospital. The blood samples were collected after the patients' informed written consent was obtained.

The following groups of patients were selected from the Database: PC with Gleason score $\geq 8$ (Gleason high, $n=24$ ), PC with Gleason score $\leq 6$ (Gleason low, $n=26$ ) and $\mathrm{BPH}$ (absence of PC confirmed by histological examination of ultrasound-guided needle biopsies and no change in the diagnosis within the follow-up period, 
$n=22$ ). Clinical data of the study population are provided in Table 1 . In addition, plasma samples from 5 PC patients and 5 healthy controls were used for the quality control of EV isolation.

\section{Isolation of extracellular vesicles}

EVs were isolated from $400 \mu \mathrm{l}$ of plasma using size exclusion chromatography (SEC). SEC columns were prepared by filling TELOS SPE columns (Kinesis, USA) with $10 \mathrm{ml}$ (bed volume) of CL6B sepharose (GE Healthcare, USA). Plasma samples were loaded on the columns and gravity-eluted with PBS. The eluate was collected in 12 sequential $0.5 \mathrm{ml}$ fractions. Each fraction was measured by Zetasizer Nano ZS (Malvern, UK) and fractions containing particles larger than $30 \mathrm{~nm}$ were combined and concentrated to $100 \mu \mathrm{l}$ using Amicon Ultra $3 \mathrm{kDa}$ centrifugal filters (Merck, Millipore, Germany).

\section{Transmission electron microscopy}

Ten $\mu \mathrm{l}$ of EV suspension in PBS were applied to 300mesh carbon coated copper EM grid and incubated for
$5 \mathrm{~min}$. Then the samples were negatively stained with $1 \%$ uranyl formate $(w / v)$ for $1 \mathrm{~min}$, dried and examined using JEM-1230 transmission electron microscope (JEOL, USA).

\section{Nanoparticle tracking analysis}

Size distribution profile and concentration of EVs was determined using NanoSight NS500 instrument (Malvern, UK). EV samples were diluted 1000-25,000 fold in PBS to achieve particle concentration in range from $1 \times 10^{8}$ to $1 \times 10^{9}$ particles $/ \mathrm{ml}$. For each sample, five $30 \mathrm{~s}$ videos were recorded with the following settings: $25 \mathrm{C}, 0.944-0.948 \mathrm{cP}$, 1259 slider shutter, 366 slider gain, and 11 camera level. The data analysis was performed with NanoSight NTA Software v3.1 Build 3.1.54 in the auto mode.

\section{Western blot}

EVs and PC-3 cells (used as a positive control) were lysed in RIPA buffer $(150 \mathrm{ml} \mathrm{NaCl}, 1 \%$ Triton X-100, $0.5 \% \mathrm{Na}$ deoxycholate, $0.1 \% \mathrm{SDS}, 50 \mathrm{ml}$ Tris) and the protein concentration was assessed using Pierce $^{\mathrm{TM}}$ BCA

Table 1 Clinical characteristics of the study population

\begin{tabular}{|c|c|c|}
\hline Characteristics & Prostate cancer, $n=50$ & Benign prostatic hyperplasia, $n=22$ \\
\hline \multicolumn{3}{|l|}{ Age (years) } \\
\hline Mean \pm SD & $66 \pm 7$ & $61 \pm 8$ \\
\hline Median (range) & $65(54-85)$ & $60(44-75)$ \\
\hline Missing & 1 & 4 \\
\hline \multicolumn{3}{|l|}{ Serum PSA (ng/ml) } \\
\hline $0-4.0$ & $3(6 \%)$ & $9(41 \%)$ \\
\hline $4.1-20.0$ & $31(62 \%)$ & $13(59 \%)$ \\
\hline$>20.0$ & 15 (30\%) & $0(0 \%)$ \\
\hline Missing & $1(2 \%)$ & $0(0 \%)$ \\
\hline \multicolumn{3}{|l|}{ Gleason score } \\
\hline $4-6$ & $26(52 \%)$ & - \\
\hline $8-9$ & $24(48 \%)$ & - \\
\hline \multicolumn{3}{|l|}{ Metastasis status } \\
\hline MO & 39 (78\%) & - \\
\hline M1 & $3(6 \%)$ & - \\
\hline Missing & $8(16 \%)$ & - \\
\hline \multicolumn{3}{|l|}{ Cancer grade } \\
\hline G1 & $0(0 \%)$ & - \\
\hline G2 & $11(22 \%)$ & - \\
\hline G3 & $12(24 \%)$ & - \\
\hline Missing & $27(54 \%)$ & - \\
\hline \multicolumn{3}{|l|}{ Prostatitis } \\
\hline- & $40(80 \%)$ & $11(50 \%)$ \\
\hline+ & $8(16 \%)$ & 11 (50\%) \\
\hline Missing & $2(4 \%)$ & $0(0 \%)$ \\
\hline
\end{tabular}


Protein Assay Kit (Thermo Fisher Scientific, USA) following manufacturer's instructions. Thirty micrograms of EV and cell proteins were mixed with Laemmli buffer under reduction conditions, denatured for $5 \mathrm{~min}$ at $100{ }^{\circ} \mathrm{C}$ and loaded on $10 \%$ SDS-PAGE gel. Proteins were electroblotted to nitrocellulose membranes and the membranes were blocked with $10 \%(w / v)$ fat-free milk and then incubated with the following primary antibodies: anti-TSG101 (Abcam, \# ab125011), Calnexin (Abcam, \# ab22595), CD9 (Santa Cruz Biotechnology, \# sc-13118) and $\beta$-actin (Abcam, \# ab8224) in 1:1000 dilution. The blots were washed and incubated with horseradish peroxidaseconjugated goat anti-rabbit IgG F(ab')2-HRP (1:2000) (Santa Cruz, \#sc-3837) or chicken anti-mouse IgG-HRP (1:2000) (Santa Cruz, \#sc-2962) secondary antibodies, respectively. Protein expression was visualized using Western Blotting Detection Reagent kit (GE HealthCare Lifesciences, Germany).

\section{Enzymatic treatment}

Prior to RNA extraction, EVs samples were treated with $1 \mathrm{mg} / \mathrm{ml}$ proteinase $\mathrm{K}$ (Thermo Fisher Scientific, USA) for $30 \mathrm{~min}$ at $37^{\circ} \mathrm{C}$. Proteinase $\mathrm{K}$ was inactivated by incubating the samples for $10 \mathrm{~min}$ at $65^{\circ} \mathrm{C}$. Then the samples were treated with $10 \mathrm{ng} / \mu \mathrm{l}$ RNase A (Thermo Fisher Scientific, USA) for $15 \mathrm{~min}$ at $37^{\circ} \mathrm{C}$.

\section{RNA extraction}

RNA was extracted from EV and whole plasma samples using miRNeasy Micro Kit (Qiagen, USA) according to the manufacturer's instructions with slight modifications of the protocol. Briefly, 5 volumes of QIAzol Lysis Reagent were added to each sample. Subsequently, samples were spiked with $1 \mu \mathrm{l}$ of UniSp6 (Exiqon, Denmark), which was used as a normaliser in downstream analysis. After adding 1 volume of chloroform samples were centrifuged for $15 \mathrm{~min}$ at $12000 \mathrm{~g}$ at $4{ }^{\circ} \mathrm{C}$ and the aqueous phase was transferred to a new tube. Then, 1.5 volumes of $100 \%$ ethanol were added to each sample and the mixture was loaded onto a MinElute spin column. Columns were centrifuged at $1000 \mathrm{~g}$ for $30 \mathrm{~s}$ at room temperature in each round until entire sample was loaded. RNA was eluted in $15 \mu \mathrm{l}$ of RNase-free water using low-bind tubes. The quantity and quality of RNA was assessed using Agilent 2100 Bioanalyzer and RNA 6000 Pico Kit (Agilent technologies, \# 5067-1513).

\section{RT-qPCR analysis}

One third of each RNA sample isolated from EVs and whole plasma was reverse-transcribed using miRCURY LNA Universal cDNA Synthesis kit II (Exiqon) according to the manufacturer's protocol. cDNA reaction mixtures were diluted 1:40 and $4 \mu \mathrm{l}$ were used for qPCR reactions. qPCR was carried out using microRNA LNA
PCR primer sets and ExiLENT SYBR Green master mix (Exiqon) according to the manufacturer's protocol on ViiA 7 Real-Time PCR system (Thermo Fisher Scientific).

\section{Statistical analysis}

$\mathrm{Ct}$ values were averaged between duplicates and normalized against UniSp6 spike-ins by subtracting them from average spike-in Ct values in the same samples, resulting in $\log 2$ relative quantities ( $\log 2 \mathrm{RQ}$ 's). The statistical analyses were performed with GraphPadPrism 5 (GraphPad, USA). A non-parametric Mann-Whitney $U$ test was used to compare the RQ values of each miRNA between the groups of samples. Multiple testing correction was done by false discovery rate (FDR) estimation and adjusted (adj.) $P$-value of $\leq 0.05$ was considered to be significant. To assess the diagnostic potential, the area under the ROC curve (AUC) was calculated for each miRNA.

\section{Results}

\section{Selection of miRNA biomarkers}

Nine miRNAs, whose levels in plasma or serum have been reported to have a diagnostic or prognostic significance in PC in at least two independent studies, were selected for this study. Studies showing their relevance for the diagnosis or prognosis of PC are summarised in Table 2. MiR-21-5p, miR-200c-3p, miR-210-3p and miR-375 have been shown to be increased in the blood of PC patients as compared to $\mathrm{BPH}$ or healthy controls consistently by two or more studies, while miR-30c-5p and miR-223-3p were found to be consistently decreased in the blood of PC patients. Inconsistent findings have been reported for Let-7a-5p, miR-141$3 p$ and miR-106a-5p.

\section{Yield and purity of EVs}

In order to compare the levels of the selected miRNAs in plasma EVs and whole plasma, each plasma sample was divided into two $400 \mu \mathrm{l}$ aliquots - one was used for the isolation of EV-incorporated RNA, while another was used directly for the isolation of cell-free RNA from whole plasma according to the workflow shown in Fig. 1a.

To assess the yield and purity of EVs, EV samples from 5 PC patients and 5 healthy controls (not included in the miRNA analysis) were characterised by transmission electron microscopy (TEM), nanoparticle tracking analysis (NTA) and Western blot analysis. TEM images revealed that the majority of particles were ranging in size from 25 to $60 \mathrm{~nm}$ that corresponds to the size of exosomes (Fig. 1b). However, as it has been shown that SEC-based EV isolation methods do not result in lipoprotein-free EV preparations [23], it cannot be excluded that a fraction of the particles are lipoproteins. NTA showed that the concentrations of EVs range from $3.14 \times 10^{10}$ to $1.27 \times 10^{12}$ particles per $\mathrm{ml}$ of plasma (Fig. 1c). The EV count was slightly increased in plasma 
Table 2 Circulating cell-free miRNA biomarkers for prostate cancer

\begin{tabular}{|c|c|c|c|c|c|c|c|}
\hline \multirow[t]{2}{*}{ miRNA } & \multicolumn{2}{|l|}{ Expression in PC tissues } & \multicolumn{5}{|c|}{ Level in blood } \\
\hline & Direction & $\overline{\text { Ref. }}$ & $\begin{array}{l}\text { Sample } \\
\text { type }\end{array}$ & Patient groups and sample size & Direction & Normalisation & Ref. \\
\hline \multirow[t]{3}{*}{$\begin{array}{l}\text { Let-7a- } \\
5 p\end{array}$} & $\begin{array}{l}\text { Down in PC vs adj. } \\
\text { Normal tissues }\end{array}$ & {$[45]$} & Serum & $\mathrm{PC}(\mathrm{n}=75), \mathrm{BPH}(n=27)$ & Down in $\mathrm{PC}$ & $\begin{array}{l}\text { RNA input and } \\
\text { miR-16, miR-425 }\end{array}$ & {$[52]$} \\
\hline & \multirow[t]{2}{*}{ Down in $\mathrm{PC}$ vs $\mathrm{BPH}$} & {$[44]$} & Serum & $\begin{array}{l}\text { High grade } P C(n=50) \text {, } \\
\text { low grade } P C(n=50) \\
\text { BPH }(n=50)\end{array}$ & $\begin{array}{l}\text { Down in high grade } \mathrm{PC} \\
\text { vs low grade } \mathrm{PC}, \mathrm{BPH}\end{array}$ & $\begin{array}{l}\text { RNA input and } \\
\text { spike-ins }\end{array}$ & [12] \\
\hline & & & Serum & $\begin{array}{l}\text { Disseminated PC }(n=20) \\
\operatorname{BPH}(n=13)\end{array}$ & Up in disseminated PC & $\begin{array}{l}\text { Spike-in and } \\
\text { miR-320a }\end{array}$ & [37] \\
\hline \multirow[t]{3}{*}{$\begin{array}{l}\operatorname{miR}-21- \\
5 p\end{array}$} & $\begin{array}{l}\text { Up in PC vs adj. Normal } \\
(n=10)\end{array}$ & {$[55]$} & Plasma & $\begin{array}{l}\operatorname{mCRPC}(n=25, \text { pooled }) \\
\text { LPC }(n=25, \text { pooled })\end{array}$ & Up in mCRPC & miR-30e & [40] \\
\hline & $\begin{array}{l}\text { Similar in PC and adj. } \\
\text { Normal tissues }(n=36)\end{array}$ & {$[56]$} & Serum & $\begin{array}{l}\text { ADPC }(n=20), \operatorname{HRPC} \\
(n=10), \operatorname{LPC}(n=20), \\
\operatorname{BPH}(n=6)\end{array}$ & Up in HRPC vs ADPC, LPC & U6 snRNA & [42] \\
\hline & $\begin{array}{l}\text { Up in PC vs } \\
\text { normal tissues }\end{array}$ & {$[57]$} & Plasma & $\begin{array}{l}P C(n=51) \\
H C(n=20)\end{array}$ & Up in PC & RNU1A snRNA & {$[43]$} \\
\hline \multirow[t]{3}{*}{$\begin{array}{l}\text { miR-30c- } \\
5 p\end{array}$} & $\begin{array}{l}\text { Up in PC vs adj. Normal } \\
\text { epithelium }(n=37)\end{array}$ & {$[58]$} & Serum & $\begin{array}{l}\text { High grade } P C(n=50) \\
\text { low grade } P C(n=50) \\
\text { BPH }(n=50)\end{array}$ & $\begin{array}{l}\text { Down in high grade PC } \\
\text { vs low grade, BPH }\end{array}$ & $\begin{array}{l}\text { RNA input and } \\
\text { spike-ins }\end{array}$ & [12] \\
\hline & \multirow[t]{2}{*}{$\begin{array}{l}\text { Up in PC vs } \\
\text { normal tissues }\end{array}$} & {$[57]$} & Plasma & $\begin{array}{l}\mathrm{PC}(n=80), \mathrm{BPH}(n=44), \\
\mathrm{HC}(n=54)\end{array}$ & Down in $\mathrm{PC}$ vs $\mathrm{BPH}, \mathrm{HC}$ & U6 snRNA & [11] \\
\hline & & & Serum & $P C(n=36), H C(n=12)$ & Down in $P C$ & RNA input & {$[51]$} \\
\hline \multirow[t]{2}{*}{$\begin{array}{l}\text { miR- } \\
106 a-5 p\end{array}$} & \multirow[t]{2}{*}{$\begin{array}{l}\text { Up in PC vs } \\
\text { normal tissues }\end{array}$} & {$[57]$} & Serum & $\begin{array}{l}\text { High grade } P C(n=50) \text {, } \\
\text { low grade } P C(n=50) \text {, } \\
\text { BPH }(n=50)\end{array}$ & Down in high grade PC & $\begin{array}{l}\text { RNA input and } \\
\text { spike-ins }\end{array}$ & [12] \\
\hline & & & Serum & $\mathrm{PC}(n=36), \mathrm{HC}(n=12)$ & Up in PC & RNA input & [51] \\
\hline \multirow[t]{10}{*}{$\begin{array}{l}\operatorname{miR}-141- \\
3 p\end{array}$} & $\begin{array}{l}\text { Up in } \mathrm{mPC}, \mathrm{PC} \text { vs } \\
\text { normal tissues }\end{array}$ & [53] & Serum & $\begin{array}{l}\text { High grade PC }(n=50) \text {, } \\
\text { low grade PC }(n=50) \\
\text { BPH }(n=50)\end{array}$ & $\begin{array}{l}\text { Detectable in }<50 \% \\
\text { of patients }\end{array}$ & $\begin{array}{l}\text { RNA input and } \\
\text { spike-ins }\end{array}$ & [12] \\
\hline & Up in PC vs BPH & {$[52]$} & Serum & $\mathrm{PC}(n=75), \mathrm{BPH}(n=27)$ & Up in PC & $\begin{array}{l}\text { RNA input and } \\
\text { miR-16, miR-425 }\end{array}$ & [52] \\
\hline & \multirow[t]{2}{*}{$\begin{array}{l}\text { Up in BCR after RP } \\
\text { vs. no BCR after RP }\end{array}$} & [59] & Plasma & $\begin{array}{l}\operatorname{mCRPC}(n=25, \text { pooled }) \\
\text { LPC }(n=25, \text { pooled })\end{array}$ & Up in $\mathrm{mCRPC}$ & miR-30e & [40] \\
\hline & & & Serum & $\begin{array}{l}\text { mCRPC }(n=26) \text {, low-risk LPC } \\
(n=28)\end{array}$ & Up in mCRCP & U6 snRNA & [53] \\
\hline & \multirow{6}{*}{$\begin{array}{l}\text { Up in } P C(n=36) \\
\text { vs normal tissue } \\
(n=36)\end{array}$} & {$[54]$} & $\begin{array}{l}\text { Plasma } \\
\text { EVs }\end{array}$ & $\mathrm{PC}(n=78), \mathrm{HC}(n=28)$ & Up in PC & Spike-ins & [38] \\
\hline & & & $\begin{array}{l}\text { Serum } \\
\text { EVs }\end{array}$ & $\begin{array}{l}\mathrm{mPC}(n=47), \text { non-recurrent } \\
\mathrm{PC}(n=72)\end{array}$ & Up in $\mathrm{mPC}$ & & \\
\hline & & & Serum & $\begin{array}{l}71 \mathrm{PC}: \mathrm{N} 1(n=48), \mathrm{NO}(n=23) \\
\mathrm{GS} \geq 8(n=29), \mathrm{GS}=7(n=42)\end{array}$ & $\begin{array}{l}\text { Up in N1 PC vs N0 PC; } \\
\text { Up in GS } \geq 8 \text { vs GS }=7\end{array}$ & Spike-ins & {$[54]$} \\
\hline & & & Plasma & $\mathrm{mPC}(n=25), \mathrm{LPC}(n=26)$ & $\begin{array}{l}\text { Up in } \mathrm{mPC} \text { vs LPC; Similar } \\
\text { in } \mathrm{PC} \text { and } \mathrm{HC}\end{array}$ & RNU1A snRNA & [43] \\
\hline & & & Serum & $m P C(n=25), H C(n=25)$ & Up in $\mathrm{mPC}$ & Spike-ins & {$[60]$} \\
\hline & & & Serum & $\begin{array}{l}P C(n=54) \text {, non-malignant } \\
(n=79)\end{array}$ & $\begin{array}{l}\text { Up in higher GS; Similar in } \\
\text { PC and non-malignant }\end{array}$ & $\begin{array}{l}\text { RNU1-4 and } \\
\text { SNORD43 }\end{array}$ & [61] \\
\hline \multirow[t]{2}{*}{$\begin{array}{l}\text { miR- } \\
200 c-3 p\end{array}$} & \multirow[t]{2}{*}{$\begin{array}{l}\text { Up in PC vs } \\
\text { normal tissue }\end{array}$} & {$[62]$} & Plasma & $\begin{array}{l}\text { mCRPC }(n=25, \text { pooled }) \\
\text { LPC }(n=25, \text { pooled })\end{array}$ & Up in mCRPC & miR-30e & [40] \\
\hline & & & Serum & $m C R P C(n=25), H C(n=25)$ & Up in $\mathrm{mCRCP}$ & Spike-ins & [41] \\
\hline \multirow[t]{2}{*}{$\begin{array}{l}\operatorname{miR}-210- \\
3 p\end{array}$} & \multirow[t]{2}{*}{ Up in PC vs BPH } & {$[44]$} & Serum & $\mathrm{PC}(n=31), \mathrm{BPH}(n=13)$ & Up in PC & $\begin{array}{l}\text { Spike-in and miR- } \\
320 a\end{array}$ & [37] \\
\hline & & & Serum & $\operatorname{mCRPC}(n=21), \mathrm{HC}(n=20)$ & Up in mCRCP & Spike-ins & [41] \\
\hline $\begin{array}{l}\text { miR-223- } \\
3 p\end{array}$ & $\begin{array}{l}\text { Up in PC vs adj. } \\
\text { Normal tissues }(n=10)\end{array}$ & [63] & Serum & & $\begin{array}{l}\text { Down in high grade PC } \\
\text { vs low grade, BPH }\end{array}$ & $\begin{array}{l}\text { RNA input and } \\
\text { spike-ins }\end{array}$ & [12] \\
\hline
\end{tabular}


Table 2 Circulating cell-free miRNA biomarkers for prostate cancer (Continued)

\begin{tabular}{|c|c|c|c|c|c|c|c|}
\hline \multirow[t]{2}{*}{ miRNA } & \multicolumn{2}{|l|}{ Expression in PC tissues } & \multicolumn{5}{|c|}{ Level in blood } \\
\hline & Direction & Ref. & $\begin{array}{l}\text { Sample } \\
\text { type }\end{array}$ & Patient groups and sample size & Direction & Normalisation & Ref. \\
\hline & & & & $\begin{array}{l}\text { High grade } P C(n=50) \text {, } \\
\text { low grade } P C(n=50) \text {, } \\
\text { BPH }(n=50)\end{array}$ & & & \\
\hline & $\begin{array}{l}\text { Up in PC vs } \\
\text { normal tissues }\end{array}$ & [57] & Serum & $P C(n=36), H C(n=12)$ & Down in $P C$ & RNA input & [51] \\
\hline \multirow[t]{6}{*}{ miR-375 } & $\begin{array}{l}\text { Up in } \mathrm{mPC}, \mathrm{PC} \\
\text { vs normal tissues }\end{array}$ & [53] & $\begin{array}{l}\text { Plasma } \\
\text { EVs }\end{array}$ & $\operatorname{CRPC}(n=100)$ & $\begin{array}{l}\text { High miRNA level } \\
\text { associated with poor OS }\end{array}$ & $\begin{array}{l}\text { RNA input and miR- } \\
\text { 30a-5p, miR-30e-5p }\end{array}$ & [39] \\
\hline & & & Serum & $\mathrm{PC}(n=31), \mathrm{BPH}(n=13)$ & Up in $P C$ & $\begin{array}{l}\text { Spike-in and miR- } \\
320 a\end{array}$ & [37] \\
\hline & $\begin{array}{l}\text { Up in } P C(n=36) \text { vs } \\
\text { normal tissue }(n=36)\end{array}$ & [54] & Plasma & $\begin{array}{l}\text { mCRPC }(n=25, \text { pooled }) \\
\text { LPC }(n=25, \text { pooled })\end{array}$ & Up in mCRPC & miR-30e & [40] \\
\hline & & & Serum & $\begin{array}{l}\text { mCRPC }(n=26), \text { low-risk } \\
\text { LPC }(n=28)\end{array}$ & Up in mCRCP & U6 snRNA & [53] \\
\hline & & & $\begin{array}{l}\text { Serum } \\
\text { EVs }\end{array}$ & $\begin{array}{l}\mathrm{mPC} \text { after } \mathrm{RP}(n=47), \\
\text { non-recurrent } \mathrm{PC} \text { after } \\
\mathrm{RP}(n=72)\end{array}$ & Up in $\mathrm{mPC}$ & Spike-ins & [38] \\
\hline & & & Serum & $\begin{array}{l}71 \text { PC: N1 }(n=48), \text { N0 } \\
(n=23), G S \geq 8(n=29) \\
\text { GS }=7(n=42)\end{array}$ & $\begin{array}{l}\text { Up in N1 PC vs NO PC; } \\
\text { similar in GS } \geq 8 \text { and GS }=7\end{array}$ & Spike-ins & [54] \\
\hline
\end{tabular}

$\overline{A D P C}$ androgen-dependent prostate cancer, $B C R$ biochemical recurrence, $B P H$ benign prostatic hyperplasia, $C R P C$ castration resistant prostate cancer, $E V s$ extracellular vesicles, $H C$ healthy control, $H R P C$ hormone-refractory prostate cancer, $L P C$ localized prostate cancer, $m C R P C$ metastatic castration resistant prostate cancer, $m P C$ metastatic prostate cancer, $P C$ prostate cancer, $R P$ radical prostatectomy

from PC patients as compared to the healthy controls (mean count in PC $7.08 \times 10^{11}$ vs $4.15 \times 10^{11}$ in healthy controls), although the difference didn't reach statistical significance in our sample set. The size distribution analysis showed that the diameter for the majority of particles was in the range from 50 to $150 \mathrm{~nm}$ with a minor fraction reaching $\sim 230 \mathrm{~nm}$ (Fig. 1d), which is somewhat inconsistent with the TEM results. This discrepancy likely has arisen due to the difference in the minimum detectable EV size between both techniques [24] and /or shrinking of EVs during fixation for TEM [25]. Western blot analysis showed that the EVs were positive for typical EV markers TSG101 and CD9, and negative for the endoplasmic reticulum protein Calnexin (Fig. 1e). Taken together, these results show that the EV isolation method used in this study results in a relatively high yield of exosome-enriched EV preparations without detectable contamination of intracellular components.

\section{RNA profiles in EVs and whole plasma}

As it has been suggested that EVs may associate with lipoproteins or protein complexes that carry cell-free miRNAs and protect them from degradation $[18,26]$, we first tested the effect of proteinase $\mathrm{K}$ and RNase A treatment on the miRNA levels in plasma EVs from three healthy individuals (Fig. 2a). Treatment of EVs with RNase A alone reduced the relative quantity (RQ) values by 15.5 to $43.6 \%$ for different miRNAs, while the treatment with proteinase $\mathrm{K}$ prior to RNase A resulted in the reduction of RQs by 50.4 to $69.3 \%$. This suggests that the proteinase $\mathrm{K}$ treatment is required for efficient removal of extra-vesicular RNA. Therefore, in order to study the intraluminal miRNAs, all EV preparations were treated with proteinase $\mathrm{K}$ and RNase A prior to the RNA extraction. RNA was extracted from EVs and whole plasma using miRNeasy Micro kit, which is designed for isolation of total RNA from small amounts of sample. Typical RNA profiles obtained by Bioanalyzer from whole plasma and EVs are shown in Fig. 2b. The profiles show the presence of small RNA peaks of 25 to 200 nt both in whole plasma and EVs, while $18 \mathrm{~S}$ and $28 \mathrm{~S}$ rRNA peaks are present in whole plasma and EVs without the enzymatic treatment (not shown) but not in the treated EVs, thus suggesting that the majority of rRNA is bound to the surface of EVs.

\section{Relative abundance of EV-incorporated miRNAs}

An equal proportion (one third) from the total RNA amount obtained from the EV and whole plasma samples of PC and BPH patients was used for the RTqPCR analysis of the 9 selected miRNA biomarkers. Spike-ins were used to control for a variation in RNA extraction, cDNA synthesis and PCR efficiency and they typically varied less than by $1 \mathrm{Ct}$. In order to assess the relative abundance of EV-enclosed miRNAs, a ratio between EV-enclosed and total cell-free miRNAs in 

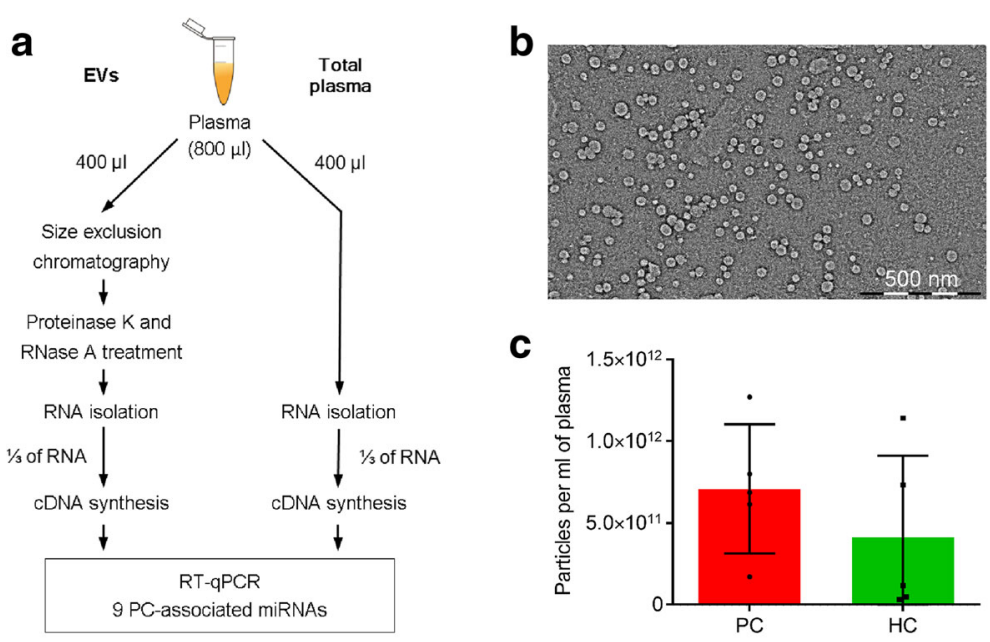

C
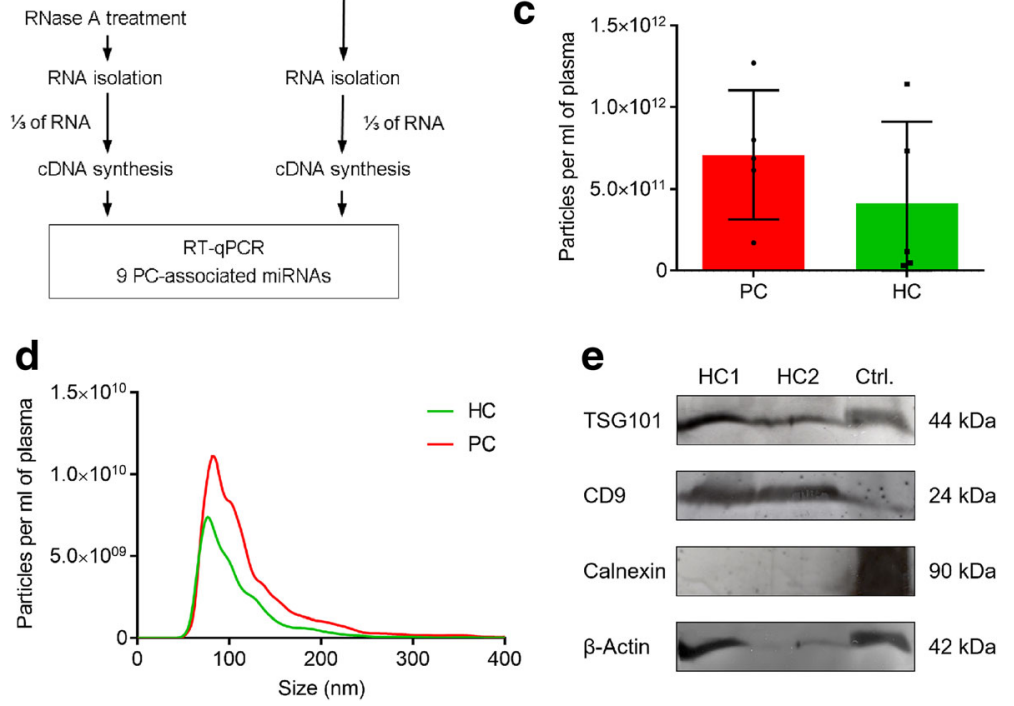

Fig. 1 Workflow of the study and characterisation of plasma EVs. a Workflow of the study. $\mathbf{b}$ Representative transmission electron microscopy image of plasma EVs. c Quantification of EVs isolated from plasma of PC patients and healthy controls (HC) by nanoparticle tracking analysis. d Average size distribution of EVs isolated from plasma of PC patients and healthy controls. e Western blot analysis of EV markers (TSG101, CD9), endoplasmic reticulum protein Calnexin and $\beta$-actin in plasma EVs isolated from two healthy individuals and PC-3 cells (as a positive control)

whole plasma was calculated (Fig. 3a). The results showed that only a small fraction of the cell-free miRNA was retrieved from the EVs. However, the EV-enclosed fraction was not uniformly low - it varied from $6.36 \%$ for Let-7a-5p to $0.65 \%$ for miR-210-3p. Spearman correlation analysis revealed only weak to moderate correlation between EV-enclosed and whole plasma cellfree miRNAs (Table 3). As an example, a paired dot plot in Fig. 3b shows the discordance in the Let-7a-5p levels in EVs and whole plasma from the same patients. These data support the idea that EV-enclosed miRNA profile differs from cell-free miRNA profile in the whole plasma.

Clearly, the size of the EV-enclosed miRNA fraction depends on the efficacy of the EV isolation method and the obtained ratios are not expected to represent the EV-enclosed: EV-free miRNA ratio. However, the NTA
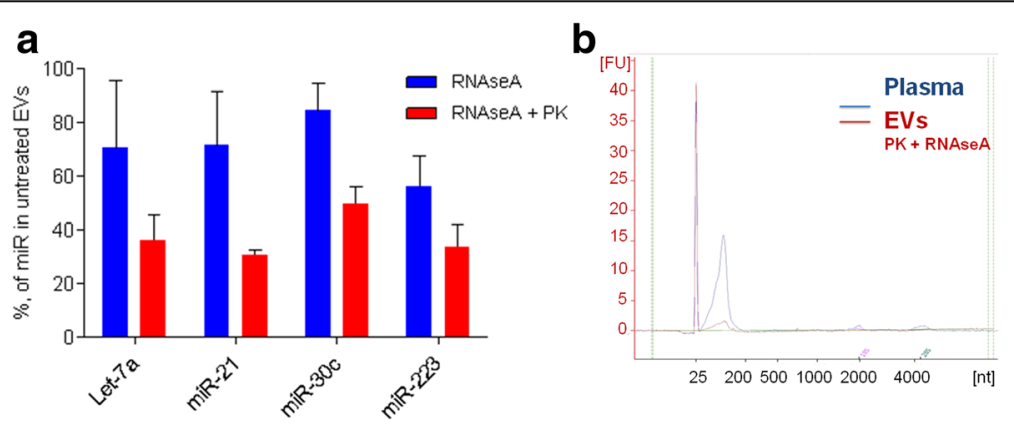

Fig. 2 Effects of proteinase $K$ and RNase A treatment on the relative quantity of EV-incorporated miRNAs and RNA profiles in whole plasma and EVs. a RT-qPCR analysis of miRNA levels in EVs treated with RNase A alone or with a combination of proteinase $\mathrm{K}$ and RNase $\mathrm{A}$ relatively to untreated EVs. Bars show the mean percentage in EVs from 3 healthy individuals. $\mathbf{b}$ A representative RNA profile from whole plasma and EVs treated with proteinase $\mathrm{K}$ and RNase A obtained by Bioanlyzer RNA 6000 Pico chip 
a

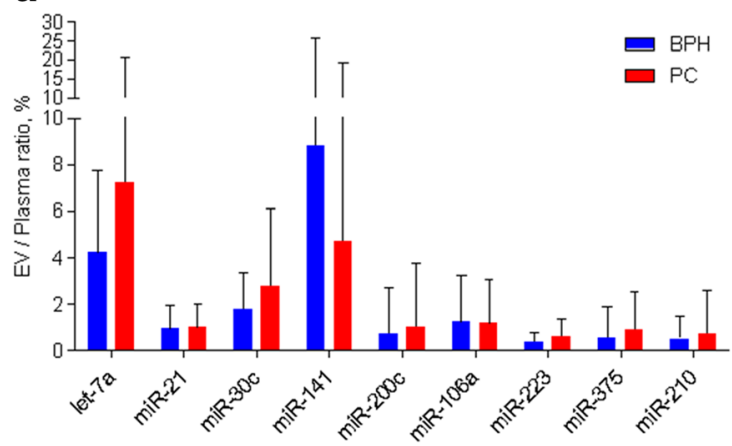

b let-7a-5p

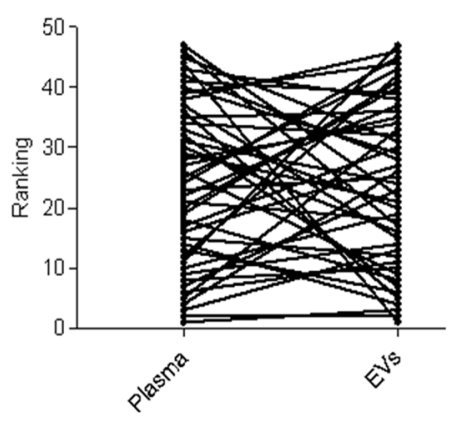

Fig. 3 Relative abundance of EV-incorporated miRNAs. a Ratio between EV-incorporated and total cell-free miRNAs in whole plasma. Bars represent the mean ratios in groups of patients with PC and BPH. $\mathbf{b}$ A paired dot plot shows the ranking of PC patients according to Let-7a-5p levels in EVs and whole plasma; lines connect the samples from the same individual

data showed that the EV count recovered in this study was similar or even higher than that reported by other studies [27-30], therefore we assume that the EV yield in our study is representative of that obtained by the current standard EV isolation techniques.

These results show that although only a small fraction of the total cell-free miRNA present in plasma was recovered from EVs, the EV-incorporated miRNA profile is clearly different from that in the whole plasma.

\section{Diagnostic potential of EV-enclosed and total cell-free miRNAs}

To assess the diagnostic potential of the selected miRNAs, their relative quantity in EVs and whole plasma was compared between patients with PC $(n=50)$ and $\mathrm{BPH}$ $(n=22)$. Three of the 9 miRNAs tested showed a diagnostic value in our sample set (Fig. 4). MiR-375 was significantly increased in PC patients as compared to BPH (FDR adj. $p=0.03$ ) and had an AUC of 0.68 (95\% CI: 0.54-0.83, $p=0.01$, when tested in the whole plasma. The same tendency was observed for EV-enclosed miR-375, however it didn't reach statistical significance. On the contrary, miR-

Table 3 Spearman correlation coefficients of EV-enclosed and whole plasma miRNAs

\begin{tabular}{llll}
\hline miRNA & Spearman $r$ & $95 \%$ confidence interval & $p$ value \\
\hline miR-375 & 0.37 & $0.15-0.56$ & 0.0013 \\
miR-141-3p & 0.36 & $0.13-0.55$ & 0.0018 \\
miR-200c-30 & 0.37 & $0.13-0.56$ & 0.0023 \\
miR-21-5p & 0.50 & $0.28-0.66$ & $<0.0001$ \\
miR-30c-5p & 0.42 & $0.19-0.60$ & 0.0005 \\
miR-106a-5p & 0.37 & $0.13-0.57$ & 0.0021 \\
miR-223-3p & 0.57 & $0.37-0.72$ & $<0.0001$ \\
Let-7a-5p & 0.27 & $0.02-0.48$ & 0.03 \\
miR-210-3p & 0.28 & $0.05-0.049$ & 0.01 \\
\hline
\end{tabular}

200c-3p and miR-21-5p could differentiate between PC and $\mathrm{BPH}$ better when tested in EVs than in the whole plasma (AUC of 0.68, $p=0.01$ and $0.67, p=0.02$, respectively, when tested in EVs and AUC of $0.62, p=0.12$ and AUC of $0.61, p=0.16$, respectively, when tested in whole plasma). The levels of the other miRNAs were not significantly different in PC samples compared to BPH neither in EVs nor in whole plasma.

Next, we investigated the association of EV-enclosed and whole plasma miRNA levels with PC aggressiveness. We found that the level of Let-7a-5p was significantly decreased in EVs from PC patients with high Gleason score $(\geq 8)$ compared to low Gleason score $(\leq 6)$ and it could differentiate between these groups with AUC of 0.68 (95\% CI: $0.52-0.84, p=0.03$ ) (Fig. 5). Although the same tendency was observed in whole plasma, the standard deviation was larger and statistical significance was not reached. No other miRNA could differentiate between PC patients with high and low Gleason scores.

Finally, none of the miRNAs was associated with the presence of histologically confirmed prostatitis in PC and $\mathrm{BPH}$ patients, thus showing that the alterations in the miRNA levels are not due to prostatic inflammation.

\section{Discussion}

Cells can release miRNAs to the extracellular space either incorporated into EVs [31,32] or in a vesicle-free form bound to various protein and lipoprotein complexes [17-20]. Quantification of these miRNAs in blood from cancer patients may offer new opportunities for diagnosis, prognosis, monitoring of treatment response and early detection of recurrence in a minimally invasive way. However, human blood contains a complex mixture of miRNAs derived from various cell types and, therefore, robust quantification of cancer-derived cell-free miRNAs has turned out to be a challenging task [14]. Currently, it is still debated if the EV-based miRNA 


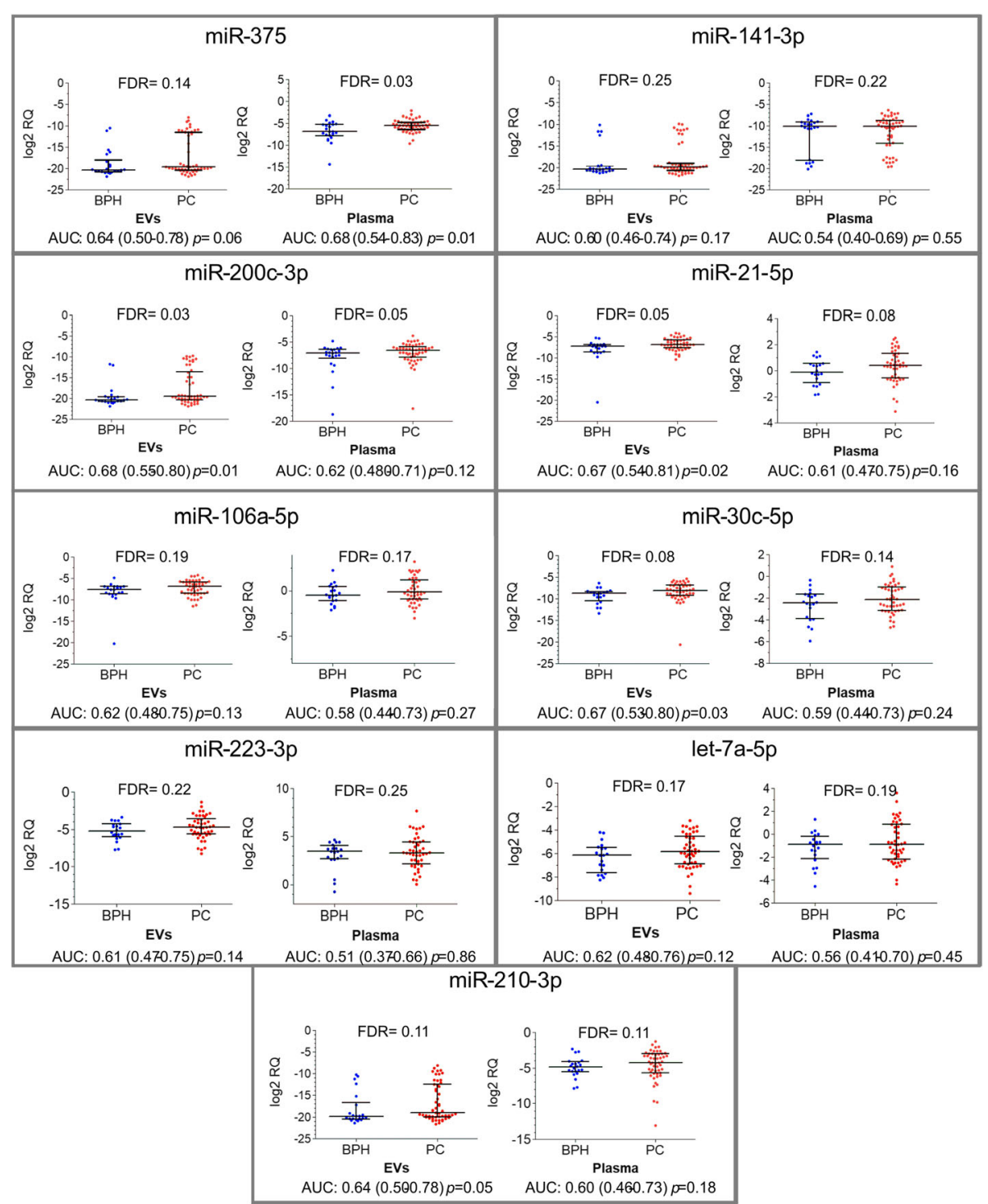

Fig. 4 Circulating miRNA levels in patients with BPH and PC. Scatter plots show the log2RQ values of each miRNA tested in EVs and in whole plasma. FDR-adjusted $p$ values are show at the top of each graph. Area under the ROC curve (AUC), 95\% confidence interval and $p$ value for differentiating between $\mathrm{PC}$ and $\mathrm{BPH}$ is shown below each graph

detection assays are superior to the whole plasma-based assays. miRNA profiles in cancer-derived EVs have been found to be reminiscent of their cell-of-origin [31, 33], though due to selective RNA sorting mechanisms they may be enriched or depleted of some specific miRNAs [34]. The EV membrane protects the RNA cargo from degradation in the bloodstream and the intraluminal RNA content is thought to be relatively stable, therefore EVs may provide a more consistent source of miRNA biomarkers than whole plasma $[15,30]$. On the other hand, it has been calculated that there is far less than one molecule of a given miRNA per EV [35], which raises the question of whether all EVs contain miRNAs and if the amounts are biologically meaningful.
Moreover, it can be argued that the EV isolation step may introduce a higher variation and result in a low RNA yield that in turn would lead to lower sensitivity, higher standard deviations and poor reproducibility of the EV-based miRNA assays as compared to whole plasma assays.

Here, we have performed a systematic comparison of miRNA levels in whole plasma and EVs isolated from the same plasma samples in a well-characterised cohort of PC and BPH patients. Our results show that EV-incorporated miRNA constitutes only a minor fraction of whole plasma miRNA. This is in line with a study by Chevillet et al. showing that exosome fractions contained a small minority of the miRNA content of plasma [35]. Nevertheless, 


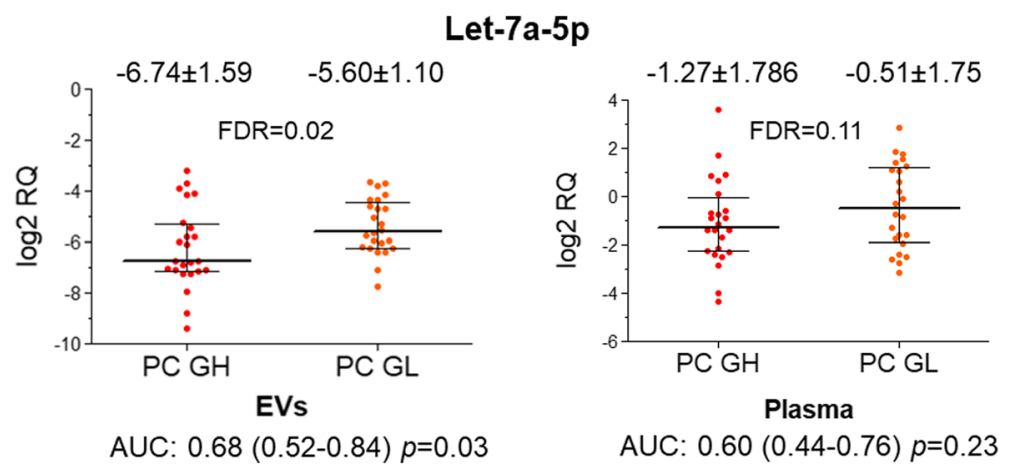

Fig. 5 Circulating Let-7a-5p levels in PC patients with low and high Gleason score. Scatter plots show the log $2 R Q$ values of Let-7a-5p tested in EVs and in whole plasma of patients with Gleason score $\geq 8(\mathrm{PC} \mathrm{GH})$ and Gleason score $\leq 6$ (PC GL). The mean log2RQ values and standard deviation is shown above each scatter plot. Area under the ROC curve (AUC), 95\% confidence interval and $p$ value for differentiating between PC patients with high and low Gleason score is shown below each graph

the miRNA levels in EVs and whole plasma were poorly correlated, and the EV-incorporated and whole plasma miRNA profile was clearly different. This finding is consistent with a NGS-based study by Cheng et al. that compared small RNA profiles in EVs, plasma and serum of 3 healthy individuals and showed that the miRNA levels differ remarkably between plasma and serum EVs and between EVs and cell-free plasma and serum [30].

Three out of 9 miRNAs analysed could differentiate between PC and BPH patients in our cohort. MiR-375 showed a better diagnostic performance when tested in whole plasma as compared to EVs. MiR-375 is an oncogenic miRNA that is overexpressed in tumours with high Gleason score and more advanced pathological stage [36]. Increased plasma or serum levels of miR-375 in patients with PC vs $\mathrm{BPH}$ or metastatic CRPC vs localised PC have been reported before in several studies (Table 2), and the AUC obtained in our study was similar to that reported before [37]. MiR-375 had one of the lowest EV to whole plasma ratios among the miRNAs analysed in this study and it was undetectable in a significant portion of EV samples. It still may have diagnostic properties in cases where it is detectable, though proving its diagnostic value would require a larger cohort of samples. Two studies have reported the presence of miR-375 in blood EVs from PC patients. Bryant et al. showed that its level is increased in serum EVs from patients with metastatic PC as compared to nonrecurring PC [38], and Huang et al. reported that high EVmiR-375 level is associated with a poor prognosis in CRPC [39]. Hence, increased levels of EV-incorporated miR-375 appear to be associated with metastatic disease. As only 3 of the patients in our cohort had a metastatic disease at the time of the blood draw, we reasonably detected it only in a minority of PC patients in our cohort. Moreover, as these studies did not describe treatment of EVs with proteinase $\mathrm{K}$, it is possible that the EV preparations also contained protein-bound miRNAs co-isolated with EVs.
On the contrary, EV-incorporated miR-200c-3p and miR21-5p showed better diagnostic performance than in whole plasma. Increased plasma or serum levels of miR-200c-3p have been found before in patients with metastatic CRPC as compared to localised PC or healthy controls [40, 41]. Similarly, miR-21-5p has been reported to be increased in plasma or serum of patients with $\mathrm{PC}$ as compared to healthy controls and patients with CRPC as compared to localised PC [40, 42, 43]. However, to the best of our knowledge, an association of EV-incorporated miR-200c-3p and miR-21-5p with PC has not been reported before. Hence, our study shows for the first time that EVs provide a better source for testing these miRNAs as PC biomarkers than whole plasma.

The only miRNA biomarker that could differentiate between PC patients with high vs low Gleason score was EV-incorporated Let-7a-5p, whose level was decreased in patients with Gleason score $\geq 8$. This is in line with a study by Mihelich et al. showing that serum levels of Let-7a were decreased in PC patients with Gleason $4+5$ grade tumours as compared with Gleason grade 3 [12]. Our study, though, shows that the whole plasma and EV levels of Let-7a-5p are poorly correlated and that EVincorporated Let7a-5p level is more informative than Let7a-5p in whole plasma.

The cellular origin of circulating miRNAs is unclear. Although it seems likely that oncogenic miRNAs such as miR-375, miR-200c-3p and miR-21-5p that are overexpressed in PC tissues are released in the bloodstream from the tumour tissues, direct evidence for this is still lacking. On the contrary, Let-7a-5p is a tumour suppressive miRNA that is downregulated in PC tissues as compared to normal or $\mathrm{BPH}$ tissues $[44,45]$. Hence, the decrease in Let-7a-5p plasma level in patients with aggressive PC is unlikely to be due to the release from cancer tissue. More plausibly, lower expression level or reduced release of Let-7a-5p is genetically associated 
with PC. Alternatively, it could be possible that signalling molecules produced by cancer cells actively downregulate the expression or release of this miRNA from normal tissues. In fact, a recent study by Chen et al. has demonstrated that breast cancer cells can downregulate the expression and release of miR-486 from cardiac and skeletal muscle in a TNFo-dependent manner [46], thus providing evidence that miRNAs released from nontumour cells can have a diagnostic significance.

We did not observe diagnostic properties for circulating miR-30c-5p, miR-106a-5p, miR-141-3p, miR-223-3p and miR-210-3p in our patient cohort. The main reasons for this could be a relatively low sample size, the usage of different RNA isolation methods and different sample storage and processing conditions that may affect miRNA abundance and stability, and different normalisation methods for RT-qPCR results. In most of these studies, the results were normalised to the RNA input. Here, we normalised the RT-qPCR data against plasma volume and spike-ins that allow controlling for experimental variation. We reasoned that the quantity of EV-RNA in our samples is by far too small to be reliably measured by the currently available RNA quantification methods (e.g. Nanodrop, Qubit or Agilent Bioanalyzer), therefore the normalisation against RNA input may lead to biased results. Moreover, as EV levels have been found to be increased in cancer patients as compared to healthy controls [47], it seems likely that the levels of EV-enclosed RNA may also be increased, hence normalisation against the RNA input may result in the loss of diagnostically relevant information. Alternative approaches for RT-qPCR data normalisation include normalisation to an individual endogenous reference gene or the geometric mean of a set of normalisers. While the selection of housekeeping genes is relatively straight-forward for miRNA expression analysis in cells or tissues, the most commonly used internal control genes have turned out to be highly variable in biofluids [48-50], therefore, there is currently no consensus on appropriate normalisers in biofluids. Possibly, the most reliable normalisation strategy is a global geometric averaging of multiple genes, however this is applicable only when large panels of miRNAs are analysed. It should also be considered that EV-miRNA and cell-free miRNAs may require different normalization genes.

Furthermore, miR-141-3p and miR-106a-5p had discordant results across publications. Increased miR-106a serum levels were shown to correlate with increased CAPRA scores in one study [51], while another study showed that it is decreased in sera from PC patients with Gleason grades $4+5$ as compared to grade 3 and $\mathrm{BPH}$ [12]. Increased serum or plasma levels of miR-141 have been found in PC patients as compared to healthy controls or $\mathrm{BPH}[1,52]$, and in patients with metastatic CRPC as compared to localised PC [40, 53, 54]. At the same time, other studies reported that miR-141 was detectable in less than $50 \%$ of patients or had similar levels in PC patients and healthy controls [43, 54].

\section{Conclusions}

To the best of our knowledge, this is the first study providing a head-to-head comparison of diagnostically relevant miRNA detection assays in whole plasma and plasma EVs from cancer patients. We show that only a minor fraction of the total cell-free miRNA could be recovered from the plasma EVs, however the EV-incorporated and whole plasma cell-free miRNA profiles were clearly different. Whole plasma MiR-375 could differentiate between PC and $\mathrm{BPH}$, while miR-200c-3p and miR-21-5p performed better when analysed in EVs. EV-incorporated but not whole plasma Let-7a-5p level could distinguish patients with aggressive and indolent PC. This shows that EVs provide a more consistent source of RNA than whole plasma for the analysis of some miRNA biomarkers, while, possibly due to specific sorting mechanisms, the abundance of other miRNAs in EVs is very low and they show better diagnostic performance in whole plasma.

\section{Abbreviations \\ AUC: Area under the curve; BPH: Benign prostatic hyperplasia; CRPC: Castration resistant prostate cancer; EV: Extracellular vesicle; miRNA: MicroRNA; PSA: Prostate specific antigen; ROC: Receiver operator curve}

\section{Acknowledgements}

We thank all the patients who participated in this study and the staff of the Latvian Genome Database for providing the samples and clinical data.

\section{Funding}

This study was supported by the Norwegian Financial Mechanism 2009-2014 under Project Contract No NFI/R/2014/045. The funding body had no role in the design of the study and collection, analysis, and interpretation of data and in writing the manuscript.

\section{Availability of data and materials}

The datasets analysed during the current study are available from the corresponding author on reasonable request.

\section{Authors' contributions}

$A L, A L I$ and $V L$ designed research, $E E, A B, V M, C B S, K S, A \bar{A}, M R$ and $A R$ performed research and participated in analysis and interpretation of the results, VM, DŠ and VL contributed to the enrolment of patients, collection and processing of clinical samples, and collection and analysis of clinical data, AL wrote the manuscript, ALI revised the manuscript. All authors have read and approved the manuscript.

Ethics approval and consent to participate

Biobanking procedures were approved by the Committee of Medical Ethics of Latvia (decision No.5, 16.09.2010) and the use of clinical samples for research was approved by the Committee of Biomedical Ethics of Riga East University Hospital (decision No. 7-A/15, 04.06.2015). The blood samples were collected after the patients' informed written consent was obtained.

Consent for publication

Not applicable.

Competing interests

The authors declare that they have no competing interests. 


\section{Publisher's Note}

Springer Nature remains neutral with regard to jurisdictional claims in published maps and institutional affiliations.

\begin{abstract}
Author details
'Latvian Biomedical Research and Study Centre, Ratsupites Str 1, k-1, Riga LV-1067, Latvia. ${ }^{2}$ Riga Stradin,š University, Dzirciema Str 16, Riga LV-1007, Latvia. ${ }^{3}$ Department of Molecular Cell Biology, Institute for Cancer Research, Oslo University Hospital-The Norwegian Radium Hospital, 0379 Oslo, Norway. ${ }^{4}$ Institute of Clinical and Preventive Medicine, Faculty of Medicine, University of Latvia, Raina blvd. 19, Riga LV - 1586, Latvia.
\end{abstract}

Received: 24 June 2017 Accepted: 30 October 2017 Published online: 09 November 2017

\section{References}

1. Mitchell PS, Parkin RK, Kroh EM, Fritz BR, Wyman SK, Pogosova-Agadjanyan EL, et al. Circulating microRNAs as stable blood-based markers for cancer detection. Proc Natl Acad Sci USA. 2008;105:10513-8.

2. Chen $X, B a$ Y, Ma L, Cai X, Yin Y, Wang K, et al. Characterization of microRNAs in serum: a novel class of biomarkers for diagnosis of cancer and other diseases. Cell Res. 2008;18:997-1006.

3. Armand-Labit $V$, Pradines A. Circulating cell-free microRNAs as clinical cancer biomarkers. Biomol Concepts. 2017;8:61-81.

4. Siegel RL, Miller KD, Jemal A. Cancer statistics, 2017. CA Cancer J Clin. 2017:67:7-30.

5. Ferlay J, Soerjomataram I, Dikshit R, Eser S, Mathers C, Rebelo M, et al. Cancer incidence and mortality worldwide: sources, methods and major patterns in GLOBOCAN 2012. Int J Cancer. 2015;136:E359-86.

6. Prensner JR, Rubin MA, Wei JT, Chinnaiyan AM. Beyond PSA: the next generation of prostate cancer biomarkers. Sci Transl Med. 2012;4:127rv3.

7. Salman JW, Schoots IG, Carlsson SV, Jenster G, Roobol MJ. Prostate specific antigen as a tumor marker in prostate cancer: biochemical and clinical aspects. Adv Exp Med Biol. 2015;867:93-114

8. Fitzpatrick JM, Bellmunt J, Fizazi K, Heidenreich A, Sternberg CN, Tombal B, et al. Optimal management of metastatic castration-resistant prostate cancer: highlights from a European expert consensus panel. Eur J Cancer. 2014;50:1617-27.

9. Bertoli G, Cava C, Castiglioni I. MicroRNAs as biomarkers for diagnosis, prognosis and Theranostics in prostate cancer. Int J Mol Sci. 2016;17:421.

10. Endzelins E, Melne V, Kalnina Z, Lietuvietis V, Riekstina U, Llorente A, et al. Diagnostic, prognostic and predictive value of cell-free miRNAs in prostate cancer: a systematic review. Mol Cancer. 2016;15:41.

11. Chen ZH, Zhang GL, Li HR, Luo JD, Li ZX, Chen GM, et al. A panel of five circulating microRNAs as potential biomarkers for prostate cancer. Prostate. 2012;72:1443-52

12. Mihelich BL, Maranville JC, Nolley R, Peehl DM, Nonn L. Elevated serum microRNA levels associate with absence of high-grade prostate cancer in a retrospective cohort. PLoS One. 2015;10:e0124245.

13. Schwarzenbach $\mathrm{H}$, Hoon DS, Pantel K. Cell-free nucleic acids as biomarkers in cancer patients. Nat Rev Cancer. 2011;11:426-37.

14. Witwer KW. Circulating microRNA biomarker studies: pitfalls and potential solutions. Clin Chem. 2015:61:56-63.

15. Huang $X$, Yuan T, Tschannen M, Sun Z, Jacob H, Du M, et al. Characterization of human plasma-derived exosomal RNAs by deep sequencing. BMC Genomics. 2013;14:319.

16. Valadi $H$, Ekstrom $K$, Bossios A, Sjostrand M, Lee JJ, Lotvall JO. Exosomemediated transfer of mRNAs and microRNAs is a novel mechanism of genetic exchange between cells. Nat Cell Biol. 2007:9:654-9.

17. Vickers KC, Palmisano BT, Shoucri BM, Shamburek RD, Remaley AT. MicroRNAs are transported in plasma and delivered to recipient cells by high-density lipoproteins. Nat Cell Biol. 2011;13:423-33.

18. Arroyo JD, Chevillet JR, Kroh EM, Ruf IK, Pritchard CC, Gibson DF, et al. Argonaute2 complexes carry a population of circulating microRNAs independent of vesicles in human plasma. Proc Natl Acad Sci USA. 2011:108:5003-8.

19. Turchinovich A, Weiz L, Langheinz A, Burwinkel B. Characterization of extracellular circulating microRNA. Nucleic Acids Res. 2011;39:7223-33.

20. Wang K, Zhang S, Weber J, Baxter D, Galas DJ. Export of microRNAs and microRNA-protective protein by mammalian cells. Nucleic Acids Res. 2010;38:7248-59.
21. Fabris L, Ceder Y, Chinnaiyan AM, Jenster GW, Sorensen KD, Tomlins S, et al. The potential of MicroRNAs as prostate cancer biomarkers. Eur Urol. 2016;70:312-22.

22. Valentino A, Reclusa P, Sirera R, Giallombardo M, Camps C, Pauwels $P$, et al. Exosomal microRNAs in liquid biopsies: future biomarkers for prostate cancer. Clin Transl Oncol. 2017;19:651-7.

23. Sodar BW, Kittel A, Paloczi K, Vukman KV, Osteikoetxea X, Szabo-Taylor K, et al. Low-density lipoprotein mimics blood plasma-derived exosomes and microvesicles during isolation and detection. Sci Rep. 2016;6:24316.

24. van der Pol E, Coumans FA, Grootemaat AE, Gardiner C, Sargent IL, Harrison $P$, et al. Particle size distribution of exosomes and microvesicles determined by transmission electron microscopy, flow cytometry, nanoparticle tracking analysis, and resistive pulse sensing. J Thromb Haemost. 2014;12:1182-92.

25. Théry C, Amigorena S, Raposo G, Clayton A. 2006. Isolation and Characterization of Exosomes from Cell Culture Supernatants and Biological Fluids. Current Protocols in Cell Biology. 30:3.22:3.22.1-3.22.29.

26. Li L, Zhu D, Huang L, Zhang J, Bian Z, Chen X, et al. Argonaute 2 complexes selectively protect the circulating microRNAs in cell-secreted microvesicles. PLoS One. 2012;7:e46957.

27. Mustapic M, Eitan E, Werner JK Jr, Berkowitz ST, Lazaropoulos MP, Tran J, et al. Plasma extracellular vesicles enriched for neuronal origin: a potential window into brain pathologic processes. Front Neurosci. 2017;11:278.

28. Hong CS, Muller L, Whiteside TL, Boyiadzis M. Plasma exosomes as markers of therapeutic response in patients with acute myeloid leukemia. Front Immunol. 2014;5:160.

29. Enderle D, Spiel A, Coticchia CM, Berghoff E, Mueller R, Schlumpberger M, et al. Characterization of RNA from Exosomes and other extracellular vesicles isolated by a novel spin column-based method. PLoS One. 2015;10:e0136133.

30. Cheng L, Sharples RA, Scicluna BJ, Hill AF. Exosomes provide a protective and enriched source of miRNA for biomarker profiling compared to intracellular and cell-free blood. J Extracell Vesicles. 2014;3:23743. http://dx.doi.org/10.3402/jev.v3.23743

31. Fiskaa T, Knutsen E, Nikolaisen MA, Jorgensen TE, Johansen SD, Perander M, et al. Distinct small RNA signatures in extracellular vesicles derived from breast cancer cell lines. PLoS One. 2016;11:e0161824.

32. Hessvik NP, Phuyal S, Brech A, Sandvig K, Llorente A. Profiling of microRNAs in exosomes released from PC-3 prostate cancer cells. Biochim Biophys Acta. 2012;1819:1154-63.

33. Lunavat TR, Cheng L, Kim DK, Bhadury J, Jang SC, Lasser C, et al. Small RNA deep sequencing discriminates subsets of extracellular vesicles released by melanoma cells-evidence of unique microRNA cargos. RNA Biol. 2015; 12:810-23.

34. Villarroya-Beltri C, Baixauli F, Gutierrez-Vazquez C, Sanchez-Madrid F, Mittelbrunn M. Sorting it out: regulation of exosome loading. Semin Cancer Biol. 2014:28:3-13.

35. Chevillet JR, Kang Q, Ruf IK, Briggs HA, Vojtech LN, Hughes SM, et al. Quantitative and stoichiometric analysis of the microRNA content of exosomes. Proc Natl Acad Sci U S A. 2014;111:14888-93.

36. Costa-Pinheiro P, Ramalho-Carvalho J, Vieira FQ, Torres-Ferreira J, Oliveira J Goncalves CS, et al. MicroRNA-375 plays a dual role in prostate carcinogenesis. Clin Epigenetics. 2015;7:42.

37. Haldrup C, Kosaka N, Ochiya T, Borre M, Hoyer S, Orntoft TF, et al. Profiling of circulating microRNAs for prostate cancer biomarker discovery. Drug Deliv Transl Res. 2014;4:19-30.

38. Bryant RJ, Pawlowski T, Catto JW, Marsden G, Vessella RL, Rhees B, et al. Changes in circulating microRNA levels associated with prostate cancer. $\mathrm{Br}$ Cancer. 2012:106:768-74.

39. Huang X, Yuan T, Liang M, Du M, Xia S, Dittmar R, et al. Exosomal miR-1290 and miR-375 as prognostic markers in castration-resistant prostate cancer. Eur Urol. 2015;67:33-41.

40. Watahiki A, Macfarlane RJ, Gleave ME, Crea F, Wang Y, Helgason CD, et al. Plasma miRNAs as biomarkers to identify patients with castration-resistant metastatic prostate cancer. Int J Mol Sci. 2013;14:7757-70.

41. Cheng HH, Mitchell PS, Kroh EM, Dowell AE, Chery L, Siddiqui J, et al. Circulating microRNA profiling identifies a subset of metastatic prostate cancer patients with evidence of cancer-associated hypoxia. PLoS One. 2013;8:e69239

42. Zhang HL, Yang LF, Zhu Y, Yao XD, Zhang SL, Dai B, et al. Serum miRNA-21: elevated levels in patients with metastatic hormone-refractory prostate cancer and potential predictive factor for the efficacy of docetaxel-based chemotherapy. Prostate. 2011;71:326-31. 
43. Yaman Agaoglu F, Kovancilar M, Dizdar Y, Darendeliler E, Holdenrieder S, Dalay $\mathrm{N}$, et al. Investigation of miR-21, miR-141, and miR-221 in blood circulation of patients with prostate cancer. Tumour Biol. 2011;32:583-8.

44. Porkka KP, Pfeiffer MJ, Waltering KK, Vessella RL, Tammela TL, Visakorpi T. MicroRNA expression profiling in prostate cancer. Cancer Res. 2007;67: 6130-5.

45. Kong D, Heath E, Chen W, Cher ML, Powell I, Heilbrun L, et al. Loss of let-7 up-regulates $\mathrm{EZ} \mathrm{H} 2$ in prostate cancer consistent with the acquisition of cancer stem cell signatures that are attenuated by BR-DIM. PLoS One. 2012;7:e33729.

46. Chen D, Goswami CP, Burnett RM, Anjanappa M, Bhat-Nakshatri P, Muller W, et al. Cancer affects microRNA expression, release, and function in cardiac and skeletal muscle. Cancer Res. 2014;74:4270-81.

47. Cappello F, Logozzi M, Campanella C, Bavisotto CC, Marcilla A, Properzi F, et al. Exosome levels in human body fluids: a tumor marker by themselves? Eur J Pharm Sci. 2017;96:93-8.

48. Hunter MP, Ismail N, Zhang X, Aguda BD, Lee EJ, Yu L, et al. Detection of microRNA expression in human peripheral blood microvesicles. PLoS One. 2008; $3:$ e3694.

49. Kok MG, Halliani A, Moerland PD, Meijers JC, Creemers EE, Pinto-Sietsma SJ. Normalization panels for the reliable quantification of circulating microRNAs by RT-qPCR. FASEB J. 2015;29:3853-62.

50. Schlosser K, McIntyre LA, White RJ, Stewart DJ. Customized internal reference controls for improved assessment of circulating MicroRNAs in disease. PLoS One. 2015;10:e0127443.

51. Moltzahn F, Olshen AB, Baehner L, Peek A, Fong L, Stoppler H, et al. Microfluidic-based multiplex qRT-PCR identifies diagnostic and prognostic microRNA signatures in the sera of prostate cancer patients. Cancer Res. 2011;71:550-60.

52. Kelly BD, Miller N, Sweeney KI, Durkan GC, Rogers E, Walsh K, et al. A circulating MicroRNA signature as a biomarker for prostate cancer in a high risk group. J Clin Med. 2015;4:1369-79.

53. Nguyen $\mathrm{HC}$, Xie W, Yang M, Hsieh CL, Drouin S, Lee GS, et al. Expression differences of circulating microRNAs in metastatic castration resistant prostate cancer and low-risk, localized prostate cancer. Prostate. 2013; 73:346-54.

54. Brase JC, Johannes M, Schlomm T, Falth M, Haese A, Steuber T, et al. Circulating miRNAs are correlated with tumor progression in prostate cancer. Int J Cancer. 2011;128:608-16.

55. Ribas J, Lupold SE. The transcriptional regulation of miR-21, its multiple transcripts, and their implication in prostate cancer. Cell Cycle. 2010;9:923-9.

56. Folini M, Gandellini P, Longoni N, Profumo V, Callari M, Pennati M, et al. miR-21: an oncomir on strike in prostate cancer. Mol Cancer. 2010;9:12.

57. Volinia S, Calin GA, Liu CG, Ambs S, Cimmino A, Petrocca F, et al. A microRNA expression signature of human solid tumors defines cancer gene targets. Proc Natl Acad Sci U S A. 2006;103:2257-61.

58. Walter BA, Valera VA, Pinto PA, Merino MJ. Comprehensive microRNA profiling of prostate cancer. J Cancer. 2013;4:350-7.

59. Tong AW, Fulgham P, Jay C, Chen P, Khalii I, Liu S, et al. MicroRNA profile analysis of human prostate cancers. Cancer Gene Ther. 2009:16:206-16.

60. Mitchell PS, Parkin RK, Kroh EM, Fritz BR, Wyman SK, Pogosova-Agadjanyan EL, et al. Circulating microRNAs as stable blood-based markers for cancer detection. Proc Natl Acad Sci U S A. 2008;105:10513-8.

61. Westermann AM, Schmidt D, Holdenrieder S, Moritz R, Semjonow A, Schmidt $M$, et al. Serum microRNAs as biomarkers in patients undergoing prostate biopsy: results from a prospective multi-center study. Anticancer Res. 2014;34:665-9.

62. Ambs S, Prueitt RL, Yi M, Hudson RS, Howe TM, Petrocca F, et al. Genomic profiling of microRNA and messenger RNA reveals deregulated microRNA expression in prostate cancer. Cancer Res. 2008;68:6162-70.

63. Wei Y, Yang J, Yi L, Wang Y, Dong Z, Liu Z, et al. MiR-223-3p targeting SEPT6 promotes the biological behavior of prostate cancer. Sci Rep. 2014:4:7546.

\section{Submit your next manuscript to BioMed Central and we will help you at every step:}

- We accept pre-submission inquiries

- Our selector tool helps you to find the most relevant journal

- We provide round the clock customer support

- Convenient online submission

- Thorough peer review

- Inclusion in PubMed and all major indexing services

- Maximum visibility for your research

Submit your manuscript at www.biomedcentral.com/submit

) Biomed Central 